一原著一

\title{
男性露出犯の犯行特徴と犯人像に関する分析
}

横田賀英子，大塚祐輔，倉石宏樹，和智妙子，渡邊和美

\author{
科学警察研究所 \\ 干277-0882 千葉県柏市柏の葉 6-3-1
}

\section{Crime scene behaviors and background characteristics of male exhibitionists}

\author{
Kaeko Yokota, Yusuke Otsuka, Hiroki Kuraishi, Taeko Wachi, and Kazumi Watanabe \\ National Research Institute of Police Science \\ 6-3-1 Kashiwanoha, Kashiwa-shi, Chiba 277-0882, Japan
}

(Received 25 March 2013; accepted 19 August 2013)

Characteristics of male offenders arrested in Japan for exhibitionism $(N=$ 414) and features of their offences were investigated. In analyses, their behavioral consistency was also examined by focusing on 87 repeat exhibitionists. The results indicated that many offenders were well-adjusted persons: $71 \%$ were employed, 30 $\%$ were married, and 23\% were graduates. Moreover, $66 \%$ of the offences were committed in daytime, and $64 \%$ targeted victims aged $10-20$ years. In $24 \%$ of cases, the distances between offenders' residences and crime scenes were less than one kilometer, whereas $40 \%$ of offenders lived over 5 kilometers away. In terms of behavioral consistency, offences in "trains or buses" and public spaces were shown to be consistent for repeated arrests, even after taking the occurrence rate into consideration by measures of adjusted standardized residual (ASR) and forward specialization coefficient (FSC), which is suggestive of behavioral consistency. Finally, less frequent behaviors, such as nighttime offences and offences targeting victims aged 30 years or older occurred less consistently in the series of offences. The results suggested that many exhibitionists rationally decided when and where to commit crimes, based on their calculation of risk and reward. The fact that many offenders were well-adjusted persons might be one of factors explaining offender's rational decision making. The findings in the current study can contribute to the police investigation to prioritize their investigative targets. The current research can form the basis of understanding of the nature of male exhibitionists.

Key words: Exhibitionist, Behavioral consistency, Adjusted standardized residual (ASR), Forward specialization coefficient (FSC), Offender profiling 


\section{緒 言}

性犯罪に打ける露出とは, 公然と性器等を露出 し，または自慰をする等のわいせつ行為をするもの を指す. 他の性犯罪と同様, 判明している大多数の 露出行為は, 男性から女性に対するものである ${ }^{1)}$.

アメリカ精神医学会による「精神疾患の診断・統 計マニュアル第 4 版 (DSM-IV-TR)」2)では, 露出 症を性嗜好異常（paraphilias）の一つとしており， その診断基準は，(A)少なくとも6力月間にわた り, 警戒していない見知らぬ人に自分の性器を露出 することに関する, 強烈な性的に興奮する空想, 性 的衝動，または行動が反復する，(B)その人が性的 衝動を行動に移している，またはその性的衝動や空 想のために, 著しい苦痛または対人関係上の困難が 生じている, とされる. 窃視症者と同様に, 露出症 者は, 多くの場合, 相手と密な接触を持とうとする ことはない。しかしながら, 窃視症者と異なり, 自 らの行為によって, ショックや驚き, 困惑といった 相手の反応を求める傾向が強い.

Davison et al. は, 臨床心理学の概説書の中で, 一般に露出症者は, 異性への接近法が未熟で, 対人 関係に困難を抱えており, 露出症者の半数以上が結 婚しているが，妻との性関係は不満足なものである と述べている3). また, Abel and Osbornは, 性嗜 好異常の治療プログラムに関わり, 露出症と診断さ れた 118 人に認められる性嗜好異常や性的な犯罪的 行為を検討した結果, 窃視症が 32 人 $(27 \%)$, 窃触 症が 20 人 $(17 \%)$, 強姦が 16 人 $(14 \%)$, 女児への非 近親姦的な小児性愛 (female nonincest pedophilia) が 15 人 $(13 \%)$, 女児への近親茹的な小児性愛（female incest pedophilia) が14人 (12\%) に認められ たことを述べている4).

露出犯の犯人特性については, 過去にこうした臨 床的な知見は幾つか散見されるが，露出犯のデモグ ラフィック的な犯人特徵について具体的に検討した 研究はほとんど見当たらない.しかしながら, 露出 犯の一般的な犯人像を把握することができれば，犯 罪捜査において優先すべき捜査対象者の属性を検討 するための基礎資料となり, 捜査にも貢献できるこ とが期待できる.さらに, 露出症者の治療に関して は，心理療法や精神療法が活用されているが1),5),
露出犯の一般的な特徵が明らかとなれば，これらの 療法を進める上で考慮すべき要因を考える際に参考 となる情報を提供することが可能になると考えられ る.

また, Davison et al. は, 前述の臨床心理学の概 説書の中で, 露出への衝動は強迫的性質をもってい るために，露出行為は同じ場所で，同じ時間に頻繁 に繰り返されることがあると述べている33. 仮に, こうした傾向が認められるのであれば，次犯行の時 間帯や場所に関する予測が可能となるため, 新たな 被害者を出さないための防犯対策や, 犯人逮捕を目 的とした警察捜査に有用な情報を提供できる。ま た，常習的な露出犯に関しては，露出での検挙歴を 複数有することが考えられるが，犯行の時間帯や場 所の一貫性が見出されれば，これらの露出累犯者に 対する前歴者捜査においても有効に活用できると考 えられる。

露出は, 発生頻度の高さに比して, 他の性犯罪と 同様, 暗数の多い罪種である.たとえば，内山らの 調査6)によると, 我が国に打ける高校生打よび大学 生の女性 676 人のうち, 調査対象者の半数弱を占め る45.3\%が, 路上で男性性器を見せられた経験を有 していたが，彼らのうち被害を公的機関に届けた り，民間機関に相談に行った者は 15 人 (2.2\%) で あった。こうした統計は, 多くの女性が露出の被害 に遭遇しやすく, 露出が比較的ありふれた犯罪であ るにもかかわらず，警察に認知されることは少ない ことを示唆している.したがって, 露出に関して は, 警察の認知件数以上に同様の犯罪が発生してい る可能性が高いことから, 警察が露出事件を認知し た場合には，より多くの事件が時間的·空間的に近 接して発生していると考えられるため, 被害拡大防 止のためには, 迅速かつ的確な捜査が必要である. しかし, これまでのところ, 露出犯の犯行特徴に関 しては, 実証的な研究はほとんど存在しない.

これを踏まえ, 本研究では, 過去にわが国で発生 した露出事件のデータを収集し, 実証的に検討する ことにより,

(1) 露出犯の犯行特徴と犯人特徵を検討すること

(2) 露出累犯者の行動一貫性について検討するこ と 
の二つを目的とした。

\section{方 法}

\section{1 分析に用いたデータ}

47都道府県警察のいずれかにおいて，2007年10月 1 日から2008年 5 月30日の間に露出の犯行で検挙さ れ，情報の収集が可能であった 415 人のうち女性を 除く男性露出犯 414 人について, 犯行特徵抢よび犯 人特徵に関する情報を警察資料より収集した。ただ し，414人の逮捕罪名は同一ではない。 また，犯行 特徵については，複数の事件で検挙されていた場合 には，収集可能であった事件資料のうち，便宜的に 最新日時の事件情報を抽出し，分析に用いた。その 結果, 分析対象となった 414 人は全て単独犯であっ た。なお，分析に用いた情報の管理は，部内の取り 決めに従い適切に行った。

また，414人のうち，露出事件で過去に検挙され た時の事件資料が収集できた者については，露出累 犯者と見なした注 1 。そして，収集された資料の中 で「最新検挙時」の事件（2007年もしくは2008年に 検挙）と「一番古い検挙時」の事件で行動がぞの程 度一致しているかについて検討した. 行動の比較に 当たっては，それぞれの検挙時において収集できた 事件資料のうち，同一人物が複数の犯行を連続的に 敢行し同時期に検挙されていた場合には，便宜的に 最新日時の事件情報を用いた。

分析対象となった露出犯414人のうち, 露出累犯 者であると特定された者は 87 人であり，全体の $21 \%$ であった．実際には露出の犯罪経歴を有するにも関 わらず，過去の事件資料が確認できなかったために 露出累犯者と特定できなかった者がいる可能性があ るが，平成20年の犯罪統計（http://www.npa.go.jp /toukei/index.htm) では, 公然わいせつで検挙さ れた成人における同一罪種の前科を有する者の比率 は $22 \%$ （1525人中 334 人）であり，本研究で特定し た露出累犯者の割合と同程度の比率である.

露出累犯者 87 人について,「最新検挙時」と「一

注1)同一人物が露出で複数の検挙歴を有する場合でも, それらの 事件が最新検挙時の事件（2007年もしくは2008年に検挙）と同 一時期の一連事件であると認められたものについては，累犯者 とはみなさなかった。
番古い検挙時」の犯行間隔を検討したところ, 中央 值は 3 年であり, 1 年末満が 7 人 $(8 \%), 1$ 年以上 5 年末満が 40 人 $(46 \%), 5$ 年以上 10 年末満が 17 人 $(20 \%) ， 10$ 年以上が 23 人 $(26 \%)$ であった。また， 同 87 人について，收集資料で確認できた露出の検挙 回数を検討したところ，2 回が61人 $(70 \%), 3$ 回が 15 人 $(17 \%), 4$ 回が 6 人 $(7 \%), 5$ 回以上が 5 人 (6\%) であり，検挙回数が 2 回の者が 7 割を占め た.

\section{2 分析に用いた変数}

本研究では，まず，露出犯の犯行特徵（犯行時間 帯，犯行場所，被害者性別，被害者年齢層，自宅一 犯行地間距離), および犯人特徵 (検挙時年齢, 最 終学歴, 職業, 配偶者の有無, 犯罪経歴) について 検討した. 各変数のカテゴリ分類については Table 1 に示したが，いずれの変数についても，欠損值は 分析から除外した.

これらのうち，犯行場所については，路上，商 業·公共施設, 駐車場 · 駐輪場, 電車 · バス, 広 場·公園, 住宅, テレビ電話の 7 分類とし, 7 分類 のいずれかにコーディングした，その際，路上には バス乗り場や河川を含めた他，広場・公園には空き 地も含めた。また，住宅には，一般住宅，集合住 宅, 寮内の犯行の他, 敷地外から敷地内の被害者に 向かって露出した者も含めた.

被害者の性別については, 性別の記載はないが被 害者の氏名が判明している場合には，氏名より性別 を判断し，氏名のみからでは男女の推定が困難であ った場合には欠損值とした。ただし, 被害者の性別 と年齢層については，複数の被害者が資料に記載さ れていた場合には，便宜的に一番目に記載されてい た被害者についてコーディング作業を行った.

自宅一犯行地間距離については，住宅地図を搭載 した地理情報システムにより計測を行った。その 際，被疑者の自宅の住所については，検挙時のもの を分析に用いた。 ただし，犯行地が電車・バスであ った 47 人と住所不定の 6 人 ( 1 人重複あり), 出会 い系サイトで知り合った被害者を対象としたテレビ 電話での犯行であった 1 人については，欠損值とし た.また, 自宅もしくは犯行地の住所の詳細が不明 であった等の理由で郡もしくは市レベルまでしか場 
所が特定できなかった者 4 人についても欠損值とし た. 郡もしくは市レベルより詳しい住所が特定でき た者については，特定できたレベルまでで距離の計 測を行った，たとえば，字レベルまで特定できた場 合には, 該当する字の任意の地点を自宅もしくは犯 行地と見なして距離計測を行った。

\section{3 行動の一貫性および反復性の指標}

複数の逮捕歴を有する露出累犯者については, 異 なる逮捕時における犯行特徵のうち, 犯行時間帯, 犯行場所, 被害者年齢層, 犯行地の管轄警察署がぞ の程度一致しているか，一致していなかった場合に はどのような移行パターンが認められるか，につい て，欠損值は分析から除外した上で検討した.

ただし，原田ら ${ }^{7)}$ は, 少年の非行種別の推移につ いて検討する中で，「ありふれた非行」を繰り返す ことが「反復性が高い」と単純に言えないこと,

「誰もが行う非行」とは区別した意味での「反復性 の高い非行」を示す指標が必要であることを指摘し た上で, 海外の犯罪経歴研究で多く用いられている 調整標準残差 (Adjusted Standardized Residual: ASR）抢よび前方特化係数（Forward Specialization Coefficient: FSC) を用いた検討を行っている.

これらは，分布の偏りによる影響を補正するための 指標である. 本研究でも, 累犯者の行動の一貫性お よび反復性の指標として, ASR および FSCを同時 に用いた。 それぞれの式は，以下に示すとおりであ る.

$$
\begin{aligned}
& A S R=\frac{O-E}{\sqrt{[1-(R / T)][1-(C R / T)]}} \\
& F S C=\frac{O-E}{R-E}
\end{aligned}
$$

$(O=$ 観測度数, $E=$ 期待度数, $R=$ 行の周辺度数, $C=$ 列の周辺度数, $T=$ データ数)

ちなみにASRは，近似的に標準正規分布にした がうため, 前回の犯行と今回の犯行とが相互に独立 だという想定を帰無仮説とし，この想定のもとでの 期待值からの各セルの観測值の乘離が, 統計的に有 意であるかどうかを検討することができる，他方， FSC は, サンプル数の大小に依存しないという特 徵をもち, 期待值と観測值とが一致する場合にゼ ロ，前回あるカテゴリだった者全員が今回特定のひ
とつのカテゴリに集中した場合に 1 の值をとるた め, 専門分化傾向などの強度を比較するための指標 として優れているという7).

\section{結 果 \\ 1 露出事件の犯行特徵亡犯人特徵}

(1) 犯行特徵

Table 1に, 本研究で分析対象となった男性露出 犯の犯行特徵について示した.

まず，時間帯や場所については，昼間の犯行が全 体の $66 \%$ ，バス・電車内を除く公共空間（路上，商 業·公共施設, 広場·公園, 駐車場・駐輪場）にお

Table 1 Crime scene behaviors of male exhibition-

\begin{tabular}{|c|c|c|}
\hline $\begin{array}{l}\text { Time of offence } \\
\quad(N=413)\end{array}$ & $\begin{array}{l}\text { Daytime }(6: 00-18: 00) \\
\text { Nighttime } \\
(18: 00-6: 00(\text { next day }))\end{array}$ & $\begin{array}{l}66 \% \\
34 \%\end{array}$ \\
\hline \multirow{7}{*}{$\begin{array}{l}\text { Place of offence } \\
\quad(N=414)\end{array}$} & Street & $40 \%$ \\
\hline & $\begin{array}{l}\text { Commercial/public } \\
\text { facility }\end{array}$ & $22 \%$ \\
\hline & Car/cycle parking space & $15 \%$ \\
\hline & Train/bus & $11 \%$ \\
\hline & Open space/park & $7 \%$ \\
\hline & Residence site & $5 \%$ \\
\hline & Television-phone & $0 \%$ \\
\hline \multirow{3}{*}{$\begin{array}{l}\text { Victim gender } \\
\quad(N=403)\end{array}$} & Female & $75 \%$ \\
\hline & Male & $10 \%$ \\
\hline & Unspecified & $15 \%$ \\
\hline \multirow{8}{*}{$\begin{array}{l}\text { Victim age } \\
(N=353)\end{array}$} & 9 years old or under & $2 \%$ \\
\hline & $10-19$ years old & $30 \%$ \\
\hline & 20-29 years old & $34 \%$ \\
\hline & $30-39$ years old & $16 \%$ \\
\hline & 40-49 years old & $8 \%$ \\
\hline & $50-59$ years old & $7 \%$ \\
\hline & 60-69 years old & $2 \%$ \\
\hline & 70 years old or over & $1 \%$ \\
\hline \multirow{8}{*}{$\begin{array}{l}\text { Distance between } \\
\text { offender's residence } \\
\text { and crime scene site } \\
\qquad(N=357)\end{array}$} & Less than $1 \mathrm{~km}$ & $24 \%$ \\
\hline & $1-2 \mathrm{~km}$ & $13 \%$ \\
\hline & $2-3 \mathrm{~km}$ & $11 \%$ \\
\hline & $3-4 \mathrm{~km}$ & $8 \%$ \\
\hline & $4-5 \mathrm{~km}$ & $4 \%$ \\
\hline & $5-10 \mathrm{~km}$ & $16 \%$ \\
\hline & $10-50 \mathrm{~km}$ & $18 \%$ \\
\hline & $50 \mathrm{~km}$ or longer & $6 \%$ \\
\hline
\end{tabular}
ists. 
ける犯行が $84 \%$ を占めた。公共空間の中でも, 特 に，路上が40\%を占め，最も多かった．なお，テレ ビ電話の該当数は 1 であったため小数点以下を四捨 五入すると $0 \%$ となったが，その具体的内容は，出 会い系サイトで知り合った被害者にテレビ電話をか けて露出を行ったものであった.

被害者の性別抢よび年齢層については, 複数の被 害者がいた場合には，便宜的に最初に記載されてい た者のみを分析対象としたが，被害者の性別につい ては，失損值を除くとデータ有効率は $97 \%$ であっ た．有効であったデータより，不特定の相手に露出 しており，資料から被害者の性別が特定できなかっ た事件（15\%）を除けば，女性が75\%を占めた。 た，被害者の年齢層については，データ有効率は 85 \%であり欠損值が多かったが，欠損值を除いた 353 人の事件については，多い順に，20歳代が $34 \% ， 10$ 歳代が30\%，30歳代が16\%であり，特に，10歳代か ら20歳代の若年層がターゲットとなる傾向が強いこ とが示された。

犯人の自宅と犯行地の距離については, 犯行地が 電車・バスもしくはテレビ電話での犯行であった 者，住所不定者，および詳細な住所が不明であった 者を除く 357 人について分析した。その結果，24\% の者が犯行地点から $1 \mathrm{~km}$ 圈未満に居住していた。

しかしながら, 居住地が犯行地点から $5 \mathrm{~km}$ 圏以上 であった者も 4 割を占めて抢り，犯人が近隣居住者 でない場合も多かった，中央值は $3 \mathrm{~km}$ （小数点以 下は四捨五入）であった。

(2) 犯人特徵

次に，犯人特徵について検討した結果を示す (Table 2).

犯人の検挙時の年齢層は，多い順に，30歳代（28 \%)，40歳代 $(23 \%) ， 20$ 歳代 (21\%) であり，20歳 代から40歳代が多くを占めた。

最終学歴のデータ有効率は $76 \%$ であったが，最終 学歴が記載されていた者 314 人のうち, 高校・短期 大学・専門学校・専修学校卒業のいずれかであった ものが50\%, 中学校もしくは養護学校卒業であった

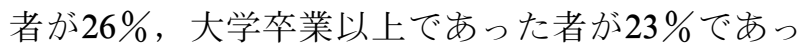
た。なお，中学校卒業には，旧制小学校抢よび青年 学校が最終学歴であった計 2 人も含まれている.ち
Table 2 Background characteristics of male exhibitionists.

\begin{tabular}{|c|c|c|}
\hline \multirow{8}{*}{$\begin{array}{l}\text { Age at arrest } \\
(N=414)\end{array}$} & $10-19$ years old & $3 \%$ \\
\hline & 20-29 years old & $21 \%$ \\
\hline & 30-39 years old & $28 \%$ \\
\hline & $40-49$ years old & $23 \%$ \\
\hline & 50-59 years old & $15 \%$ \\
\hline & 60-69 years old & $8 \%$ \\
\hline & 70-79 years old & $2 \%$ \\
\hline & 80 years old or over & $1 \%$ \\
\hline \multirow{3}{*}{$\begin{array}{l}\text { Academic } \\
\text { background } \\
(N=314)\end{array}$} & $\begin{array}{l}\text { Junior high school/ } \\
\text { school for the disabled }\end{array}$ & $26 \%$ \\
\hline & $\begin{array}{l}\text { High school/two-year } \\
\text { college/career college/ } \\
\text { special training school }\end{array}$ & $50 \%$ \\
\hline & University & $23 \%$ \\
\hline \multirow{2}{*}{$\begin{array}{l}\text { Occupation } \\
(N=414)\end{array}$} & Employed & $71 \%$ \\
\hline & Unemployed & $30 \%$ \\
\hline \multirow{2}{*}{$\begin{array}{l}\text { Marriage status } \\
\quad(N=414)\end{array}$} & Married & $30 \%$ \\
\hline & $\begin{array}{l}\text { Married in past/having } \\
\text { child }\end{array}$ & $2 \%$ \\
\hline \multirow{2}{*}{$\begin{array}{c}\text { Criminal history } \\
(N=411)\end{array}$} & Any & $52 \%$ \\
\hline & None & $49 \%$ \\
\hline
\end{tabular}

なみに, 先行研究では, 男性の年少者強姦犯の大卒 者の割合は $2.5 \%^{8)}, 13$ 歳以上の女性被害の屋外での 男性強制わいせつ犯で犯行時に加害者々被害者の面 識がなかった者の大卒者の割合は6.7\% ${ }^{91}$ であり，本 研究に拈ける露出犯のデータにおいて大卒者が $23 \%$ を占めたという結果は，強姦や強制わいせつといっ た他の接触型の性犯罪と比較すると高い比率である と考えられる.

職業に関しては，アルバイトも含めると $71 \%$ ア有 職者であったが, 職種は様々であった。 有職者の職 種を詳細に検討すると，全414人のうち，会社員・ 公務員 · 経営者 · 団体専従もしくは農林漁業従事者 等が $31 \%$, 職人.手職.工員・労務者等が $28 \%$, 飲 食営業・風俗関係者が $8 \%$, 自由業が $2 \%$, セール スマン・集金人等が $1 \%$ であり，比較的安定した職 に就き生計を立てていると考えられる者が多く認め られた。また, 無職者 30\%のうち, 学生が 3\%であ った.

また，婚姻状況に関しては，記載のない者や，内 妻，交際者がいることのみ確認できた者が $68 \%$ を占 
めた一方で注 2 , 妻帯者であることが確認できた者 も30\%認められた. 妻帯者以外の者の中で離婚歴を 有することが明確であるか, 結婚歴は不明であるが 子どもがいることが確認できた者は $2 \%$ であった.

犯罪経歴については，3 人は不明であったが，残 りの411人については，何らかの犯罪経歴を有する 者が52\%を占めた．犯罪経歴の内訳について検討す ると, 最も多くを占めたのはわいせつであり, 全体 の $29 \%$ であった. わいせつには, 強茹, 強制わいせ つ，公然わいせつ，わいせつ物頒布等が該当する が, 本研究で用いたデータでは, 強姦もしくは強制 わいせつであることが確認できた場合にはわいせつ に含めず，それぞれ別個にカウントした。性的要素 を含む可能性のある罪種において，次に比率が高か ったのは，迷惑防止条例違反と住居侵入であり，そ れぞれ全体の 9\%の者がこれらの犯罪経歴を有して いた。一方で, 強制わいせつや強茹（強盗強茹を含 む）といった接触型の性犯罪の犯罪経歴を有してい たことが確認できた者は，それぞれ 3\%と $1 \%$ であ り, あまり多く認められなかった。 また, 風営適正 化法もしくは青少年条例違反に該当した者も $1 \%$ で 認められた. ちなみに, 露出累犯者であることが確 認できた者は 87 人 $(21 \%)$ であったが，その87人か ら犯罪経歴の詳細が不明であった者を除いた86人に おいても，強制わいせつの犯罪経歴を有することが 確認できた者は 7\%, 強姦歴を有することが確認で きた者は $2 \%$ にとどすった．また，性的犯罪以外で 多く認められたのは窃盗歴(占有離脱物横領を含む) であり，全体の $18 \%$ が該当した. 粗暴犯歴（暴行. 傷害・暴力行為・恐掲）を有していた者は $8 \%$ ，凶 悪犯歴（殺人, 強盗，放火）を有していた者は $2 \%$ であった。

\section{2 露出累犯者の行動一貫性と移行性}

次に, 露出累犯者であることが確認された者 $(87$ 人)について,「犯行時間帯」,「犯行場所」,「被害 者年齢層」,「犯行地の管轄警察署」の 4 変数の一貫

注2)配偶者や子に関しては, 参照した書類のいずれかの欄に配偶 者もしくは子について何らかの記載があった場合に, 既婚者や 結婚歴あり（もしくは子あり）と見なした. したがって, カウ ントされなかった場合には, 独身である場合と, 配偶者がいて も参照した書類に記載されていなかった場合の 2 通りの可能性 がある。
Table 3-1 Categories of "Time of offence" of the most recent and oldest cases $(N=79)$.

\begin{tabular}{ccccc}
\hline & & \multicolumn{2}{c}{ Oldest cases } & \multirow{2}{*}{ Total } \\
\cline { 3 - 3 } Most & \multicolumn{1}{c}{1 Daytime } & 2 & \\
\hline $\begin{array}{c}(6: 00-18: 00) \\
\text { recent }\end{array}$ & $41(71 \%)$ & $17(29 \%)$ & $58(100 \%)$ \\
cases & $\begin{array}{c}\text { (18:00-6:00 } \\
(\text { next day) })\end{array}$ & $10(48 \%)$ & $11(52 \%)$ & $21(100 \%)$ \\
\hline & 合 計 & $51(65 \%)$ & $28(35 \%)$ & $79(100 \%)$ \\
\hline
\end{tabular}

Concordance rate $=66 \%$

Cramer's $V=0.21$

\begin{tabular}{|c|c|c|c|}
\hline \multicolumn{4}{|c|}{ Adjusted Standardized Residual (ASR) } \\
\hline & & \multicolumn{2}{|c|}{ Oldest cases } \\
\hline & & 1 & 2 \\
\hline Most & 1 Daytime $(6: 00-18: 00)$ & 1.89 & -1.89 \\
\hline $\begin{array}{l}\text { recent } \\
\text { cases }\end{array}$ & $\begin{array}{l}2 \text { Nighttime } \\
(18: 00-6: 00 \text { (next day }))\end{array}$ & -1.89 & 1.89 \\
\hline \multicolumn{4}{|c|}{ NOTE) ${ }^{*}: p<.05,{ }^{* *}: p<.01$} \\
\hline \multicolumn{4}{|c|}{ Forward Specialization Coefficient (FSC) } \\
\hline & & \multicolumn{2}{|c|}{ Oldest cases } \\
\hline & & 1 & 2 \\
\hline Most & 1 Daytime (6:00-18:00) & 0.17 & -0.09 \\
\hline $\begin{array}{l}\text { recent } \\
\text { cases }\end{array}$ & $\begin{array}{l}2 \text { Nighttime } \\
(18: 00-6: 00 \text { (next day) })\end{array}$ & -0.48 & 0.26 \\
\hline
\end{tabular}

性と移行性について検討した．前者 3 変数について は, Table 3-1から Table 3-3に「最新検挙時」と 「一番古い検挙時」の事件の行動を比較した結果を 示した. 各表にはそれぞれ, 変数の出現頻度に関す るクロス集計, ASR, FSC が記載されている.

まず，犯行時間帯については, Table 3-1に示す ように, 全体のカテゴリ一致率は $66 \%$, クラメール

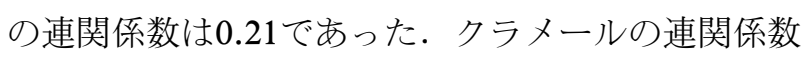
について，菅 ${ }^{10)} は ， 0.25$ 以上 0.5 未満であれば両者 の間にやや強い連関があるとの基準を示している が，この基準にしたがえば，犯行時間帯の連関は低 いとみなすことができる. 各カテゴリについて検討 すると，「最新検挙時」が昼間 $(6: 00 \sim 18: 00) の$ 犯人では, 「一番古い検挙時」の事件でも昼間の犯 行であった者は71\%であった。他方，「最新検挙時」 の犯行が夜間（18：00〜翌日6：00）であった場合 
Table 3-2 Categories of "Place of offence" of the most recent and oldest cases $(N=82)$.

\begin{tabular}{|c|c|c|c|c|c|c|c|}
\hline & \multicolumn{5}{|c|}{ Oldest cases } & \multirow{2}{*}{ Total } \\
\hline & & 1 & 2 & 3 & 5 & 6 & \\
\hline \multirow{6}{*}{$\begin{array}{l}\text { Most } \\
\text { recent } \\
\text { cases }\end{array}$} & 1 Street & $21(57 \%)$ & $3(8 \%)$ & $2(5 \%) 5(1$ & 1\%) $3(8 \%)$ & $3(8 \%)$ & $37(100 \%)$ \\
\hline & 2 Commercial/public facility & $4(24 \%)$ & $9(53 \%)$ & $4(24 \%) \quad 0($ & $\%) 0(0 \%)$ & $0(0 \%)$ & $17(100 \%)$ \\
\hline & 3 Train/bus & $0(0 \%)$ & $2(18 \%)$ & $9(82 \%) \quad 0($ & $\%) \quad 0(0 \%)$ & $0(0 \%)$ & $11(100 \%)$ \\
\hline & 4 Open space/park & $3(38 \%)$ & $1(13 \%)$ & $0(0 \%) \quad 2(2$ & $\% \%) \quad 1(13 \%)$ & $1(13 \%)$ & $8(100 \%)$ \\
\hline & 5 Car/cycle parking space & $2(33 \%)$ & $2(33 \%)$ & $0(0 \%) \quad 0($ & $\%) \quad 2(33 \%)$ & $0(0 \%)$ & $6(100 \%)$ \\
\hline & 6 Residence site & $3(100 \%)$ & $0(0 \%)$ & $0(0 \%) \quad 0($ & $\%) \quad 0(0 \%)$ & $0(0 \%)$ & $3(100 \%)$ \\
\hline & 計 & $33(40 \%)$ & $17(21 \%)$ & $15(18 \%) \quad 7($ & $\%) 6(7 \%)$ & $4(5 \%)$ & $82(100 \%)$ \\
\hline \multicolumn{8}{|c|}{$\begin{array}{l}\text { Concordance rate }=52 \% \\
\text { Cramer's } V=0.44\end{array}$} \\
\hline \multicolumn{8}{|c|}{ Adjusted Standardized Residual (ASR) } \\
\hline & & \multicolumn{6}{|c|}{ Oldest cases } \\
\hline & & 1 & 2 & 3 & 4 & 5 & 6 \\
\hline \multirow{6}{*}{$\begin{array}{l}\text { Most } \\
\text { recent } \\
\text { cases }\end{array}$} & 1 Street & $2.76^{* *}$ & $-2.56^{*}$ & $-2.74^{* *}$ & 1.46 & 0.25 & 1.23 \\
\hline & 2 Commercial/public facility & -1.58 & $3.68^{*}$ & 0.63 & -1.41 & -1.30 & -1.05 \\
\hline & 3 Train/bus & $-2.93^{* *}$ & -0.22 & $5.86^{* *}$ & -1.09 & -1.00 & -0.81 \\
\hline & 4 Open space/park & -0.17 & -0.60 & -1.41 & 1.75 & 0.59 & 1.05 \\
\hline & 5 Car/cycle parking space & -0.36 & 0.79 & -1.20 & -0.78 & $2.54^{*}$ & -0.58 \\
\hline & 6 Residence site & $2.15^{* *}$ & -0.90 & -0.83 & -0.54 & -0.50 & -0.40 \\
\hline
\end{tabular}

NOTE) ${ }^{*}: p<.05,{ }^{* *}: p<.01$.

Forward Specialization Coefficient (FSC)

\begin{tabular}{|c|c|c|c|c|c|c|c|}
\hline & \multicolumn{6}{|c|}{ Oldest cases } \\
\hline & & 1 & 2 & 3 & 4 & 5 & 6 \\
\hline \multirow{6}{*}{$\begin{array}{l}\text { Most } \\
\text { recent } \\
\text { cases }\end{array}$} & 1 Street & 0.28 & -0.16 & -0.16 & 0.05 & 0.01 & 0.03 \\
\hline & 2 Commercial/public facility & -0.28 & 0.41 & 0.06 & -0.09 & -0.08 & -0.05 \\
\hline & 3 Train/bus & -0.67 & -0.03 & 0.78 & -0.09 & -0.08 & -0.05 \\
\hline & 4 Open space/park & -0.05 & -0.10 & -0.22 & 0.18 & 0.06 & 0.08 \\
\hline & 5 Car/cycle parking space & -0.12 & 0.16 & -0.22 & -0.09 & 0.28 & -0.05 \\
\hline & 6 Residence site & 1.00 & -0.26 & -0.22 & -0.09 & -0.08 & -0.05 \\
\hline
\end{tabular}

には，過去も夜間であった者は $52 \%$ であり，昼間の 場合よりも一致率は低かった。 また，「最新検挙時」 々「一番古い検挙時」の事件の犯行時間の差で検討 した場合，差が 3 時間未満であった者が $46 \% ， 3$ 時 間以上 6 時間未満であった者が $17 \% ， 6$ 時間以上 9 時間未満であった者が $15 \% ， 9$ 時間以上 12 時間未満 であった者が $22 \%$ であった。すなわち，6時間未満 の者が 6 割強であり, 露出累犯者の多くが比較的近 接した時間帯の犯行を繰り返していたことを示す. ただし，ASR 抽びFCによって，分布の偏りを 補正し，犯行時間帯の一貫性抢よび移行性を検討し
た結果では, FSCについては, カテゴリが一致す るセルについては, 正の值が得られ, カテゴリが不 一致のセルについては負の值が得られたが，ASR はいずれのセルも統計的に有意ではなかった.

犯行場所については, Table 3-2 に示すように, 全体のカテゴリ一致率は $52 \%$, クラメールの連関係

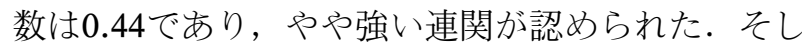
て, 電車・バスの発生であった場合に一致率が最も 高く, 「最新検挙時」の犯行が電車・バスであった 者のうち，82\%が「一番古い検挙時」においても電 車・バスの犯行であった。 また,「最新検挙時」が， 
Table 3-3 Categories of "Victim age" of the most recent and oldest cases $(N=65)$.

\begin{tabular}{|c|c|c|c|c|c|c|c|c|c|}
\hline & \multicolumn{7}{|c|}{ Oldest cases } & \multirow{2}{*}{ Total } \\
\hline & & 1 & 2 & 3 & 4 & 5 & 6 & 7 & \\
\hline \multirow{8}{*}{$\begin{array}{l}\text { Most } \\
\text { recent } \\
\text { cases }\end{array}$} & 19 years old or under & $0(0 \%)$ & $2(100 \%)$ & $0(0 \%)$ & $0(0 \%)$ & $0(0 \%)$ & $0(0 \%)$ & $0(0 \%)$ & $2(100 \%)$ \\
\hline & $210-19$ years old & $0(0 \%)$ & $13(59 \%)$ & $3(14 \%)$ & $5(23 \%)$ & $0(0 \%)$ & $0(0 \%)$ & $1(5 \%)$ & $22(100 \%)$ \\
\hline & $320-29$ years old & $0(0 \%)$ & $6(27 \%)$ & $9(41 \%)$ & $5(23 \%)$ & $1(5 \%)$ & $1(5 \%)$ & $0(0 \%)$ & $22(100 \%)$ \\
\hline & $430-39$ years old & $0(0 \%)$ & $3(38 \%)$ & $5(63 \%)$ & $0(0 \%)$ & $0(0 \%)$ & $0(0 \%)$ & $0(0 \%)$ & $8(100 \%)$ \\
\hline & 5 40-49 years old & $0(0 \%)$ & $1(25 \%)$ & $2(50 \%)$ & $1(25 \%)$ & $0(0 \%)$ & $0(0 \%)$ & $0(0 \%)$ & $4(100 \%)$ \\
\hline & $650-59$ years old & $0(0 \%)$ & $2(33 \%)$ & $3(50 \%)$ & $1(17 \%)$ & $0(0 \%)$ & $0(0 \%)$ & $0(0 \%)$ & $6(100 \%)$ \\
\hline & $760-69$ years old & $0(0 \%)$ & $1(100 \%)$ & $0(0 \%)$ & $0(0 \%)$ & $0(0 \%)$ & $0(0 \%)$ & $0(0 \%)$ & $1(100 \%)$ \\
\hline & 計 & $0(0 \%)$ & $28(43 \%)$ & $22(34 \%)$ & $12(19 \%)$ & $1(2 \%)$ & $1(2 \%)$ & $1(2 \%)$ & $65(100 \%)$ \\
\hline
\end{tabular}

Concordance rate $=34 \%$

Cramer's $V=0.24$

Adjusted Standardized Residual (ASR)

\begin{tabular}{|c|c|c|c|c|c|c|c|c|}
\hline & & \multicolumn{7}{|c|}{ Oldest cases } \\
\hline & & 1 & 2 & 3 & 4 & 5 & 6 & 7 \\
\hline \multirow{7}{*}{$\begin{array}{l}\text { Most } \\
\text { recent } \\
\text { cases }\end{array}$} & 19 years old or under & $\cdot$ & 1.65 & -1.03 & -0.68 & -0.18 & -0.18 & -0.18 \\
\hline & $210-19$ years old & . & 1.86 & $-2.46^{*}$ & 0.63 & -0.72 & -0.72 & 1.41 \\
\hline & $320-29$ years old & . & -1.84 & 0.86 & 0.63 & 1.41 & 1.41 & -0.72 \\
\hline & 4 30-39 years old & . & -0.34 & 1.83 & -1.44 & -0.38 & -0.38 & -0.38 \\
\hline & 5 40-49 years old & . & -0.75 & 0.70 & 0.35 & -0.26 & -0.26 & -0.26 \\
\hline & $650-59$ years old & . & -0.51 & 0.88 & -0.12 & -0.32 & -0.32 & -0.32 \\
\hline & 7 60-69 years old & . & 1.16 & -0.72 & -0.48 & -0.13 & -0.13 & -0.13 \\
\hline
\end{tabular}

NOTE) ${ }^{*}: p<.05,{ }^{* *}: p<.01$.

Forward Specialization Coefficient (FSC)

Oldest cases

\begin{tabular}{|c|c|c|c|c|c|c|c|c|}
\hline & & 1 & 2 & 3 & 4 & 5 & 6 & 7 \\
\hline \multirow{7}{*}{$\begin{array}{l}\text { Most } \\
\text { recent } \\
\text { cases }\end{array}$} & 19 years old or under & 0.00 & 1.00 & -0.51 & -0.23 & -0.02 & -0.02 & -0.02 \\
\hline & $210-19$ years old & 0.00 & 0.28 & -0.31 & 0.05 & -0.02 & -0.02 & 0.03 \\
\hline & $320-29$ years old & 0.00 & -0.28 & 0.11 & 0.05 & 0.03 & 0.03 & -0.02 \\
\hline & 4 30-39 years old & 0.00 & -0.10 & 0.43 & -0.23 & -0.02 & -0.02 & -0.02 \\
\hline & 5 40-49 years old & 0.00 & -0.32 & 0.24 & 0.08 & -0.02 & -0.02 & -0.02 \\
\hline & $650-59$ years old & 0.00 & -0.17 & 0.24 & -0.02 & -0.02 & -0.02 & -0.02 \\
\hline & 7 60-69 years old & 0.00 & 1.00 & -0.51 & -0.23 & -0.02 & -0.02 & -0.02 \\
\hline
\end{tabular}

路上や，商業・公共施設であった場合も，それぞれ $57 \%, 53 \%$ で一番古い検挙時においても同カテゴリ の犯行であった。他方, 広場·公園, 駐車場・駐輪 場については，同カテゴリの犯行の一致率は $25 \%$, 33\%であった。しかしながら, 路上, 商業・公共施 設, 広場·公園, 駐車場・駐輪場を包括して, 乗り 物を除く「公共空間」といった枠組みで捉えると， 「最新検挙時」に「公共空間」の犯行であった者の
うち $71 \%$ が，一番古い検挙時の事件でも「公共空間」 での犯行を行って抢り，一致率はかなり高かった。 また，ASR およびFSCによって分布の偏りを補正 して一貫性㧍よび移行性を検討した結果では，FSC については，カテゴリ一致の該当数がゼロであった 住宅以外では，カテゴリが一致するセルについては 正の值が得られ，それらのASR も広場・公園以外 では統計的に有意であった，特に，「最新検挙時」, 
「一番古い検挙時」の双方が電車・バスであるセル については, FSCが 0.78 と最も高く, 次いで, 商 業・公共施設（0.41）が高かった。 また，「最新検 挙時」,「一番古い検挙時」の双方が，上述の「公共 空間」であった場合の ASR は4.00 $(p<.05)$ であ り，構成比の大きさを補正しても「公共空間」の一 貫性は高いことが示された.

被害者年齢層については，全体のカテゴリ一致率

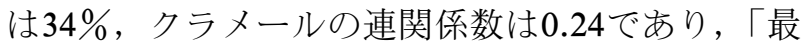
新検挙時」と「一番古い検挙時」の連関は低かった. 「最新検挙時」々「一番古い検挙時」の一致率が高 かったのは，10歳代（59\%）と20歳代（41\%）であ った（Table 3-3）. ASR および FSCによって分布 の偏りを補正して一貫性および移行性を検討した結 果では, ASRについては, 被害者年齢層が 20 歳代 から10歳代に移行した者が該当するセルのみが 5\% で負の方向に有意であった他は，有意なセルは存在 しなかった。 また，「最新検挙時」に30歳代以上の 被害者をターゲットにしていた者については，いず れもサンプル数は 1 桁で少なかったが，「最新検挙 時」の被害者年齢層が60歳代であった 1 名が過去に 10歳代の被害者をターゲットにしていたことを除け ば，過去の検挙時には20歳代をターゲットにしてい た者が該当するセルが他の年齢層よりも高く, FSC も正の值であった。この結果は，「最新検挙時」に 30歳代以上の被害者をターゲットにしていた者の多 くが，「一番古い検挙時」には20歳代の被害者をター ゲットにしていたことを示す。

最後に，表に記載はないが，「最新検挙時」と 「一番古い検挙時」の犯行地の管轄警察署について 検討した結果，累犯者 87 人のうち，「最新検挙時」 と同一の警察署管内で「一番古い検挙時」の事件を 行っていた者が $27 \%$, 同一都道府県内の異なる警察 署管内で犯行を行っていた者が51\%，異なる都道府

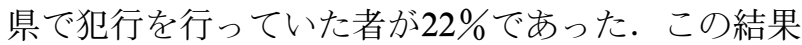
は，同一警察署管内での犯行を繰り返していた者が 3 割程度いた一方で, 過去の犯行場所が異なる府県 であった者も，2 割以上いたことを示している.

\section{考 察}

分析の結果，わが国における露出事件の主特徵と
して, 昼間の犯行が 7 割弱, 10歳代から20歳代の被 害者を対象とした犯行が 6 割強を占めることが見出 された。 また，不特定の被害者に露出しており，被 害者の性別が特定できなかったものが $15 \%$ を占めた 他は， 7 割強が女性であった。これらの特徵は，犯 人が，潜在的な被害対象者に容易に遭遇できるであ ろう場所や時間帯を選択した結果であると考えられ る。また，時間帯に関しては，昼間であれば，視認 性が高く, 露出もより効果的であるという理由に起 因している可能性もあるだろう。

犯人の自宅から犯行地までの距離については， 2 割強が犯行地点から $1 \mathrm{~km}$ 圏未満に居住していた一 方で, 車両もしくは公共交通機関が必要と思われる $5 \mathrm{~km}$ 圈以上に居住していた者も 4 割を占めた。自 宅の住所については, 検挙時の住所を分析に用いた ため, 転居等で自宅が移転した可能性はあるが，露 出が必ずしも, 自宅近隣で衝動的に行われる犯行で はないことが示唆された。

これらの結果は，犯人にとって，自宅から現場ま での近さよりも，自分の見知っている人物に遭遇す るリスクや逮捕リスクを低くすること, もしくは潜 在的な被害者に遭遇する可能性がより高いであろう 場面を選択することの方が重要であることを示唆し ている. 藤岡 ${ }^{11)}$ は, 意図的に被害者と加害状況を選 択するという点に抢いて，多くの性暴力は自身の欲 求を充足させるという目的に沿った，合目的的行動 であることを述べている. 露出は, 被害者との接触 が短時間で, 被害者とのインタラクションもほとん どないことから, 綿密な準備や計画性は強姦や強制 わいせつといった接触型の性犯罪ほど求められない 犯罪であるにも関わらず, 露出犯も他の接触型の性 犯罪と同様に，逮捕のリスクと，潜在的被害者への 遭遇しやすさといった報酬を計算した上で，自分が 適切と考える時間および場所において犯行に及ぶと いう合理的選択理論の枠組みに沿った犯行を行うこ とが比較的多いことが考えられる。

犯人特徵については，20歳代から40歳代が多くを 占めた. そして, 半数強が犯罪経歴を有していた一 方で, 大卒の高学歷者, 有職者, 妻帯者等, 一見, 社会的にうまく適応していると考えられる者も見出 された。特に，大卒の占める割合が $23 \%$ であった 
が, これは, 過去の研究から見出されている接触型 の性犯罪と比較すると, 高い比率であった。 また, 職業についても, 会社員·公務員·経営者 · 団体専 従もしくは農林漁業従事者等が $31 \%$ を占めており, 安定した職に就き生計を立てていると考えられる者 が少なくなかった。これらの結果は, 露出が接触型 の性犯罪と比較すると, 比較的社会適応のよい者で あっても犯行に至ることのある犯罪であることを示 唆している.そして, こうした犯人像は, 露出犯の 多くが，リスクと報酬を計算した上で，犯行の時間 帯や場所を合理的に選択して犯行に及んでいると考 えられることとも適合すると考えられる.

また, 犯罪経歴に関しては, 強姦や強制わいせつ を除くわいせつや窃盗歴を有する者がそれぞれ 2,3 割程度いた一方で, 同じ性犯罪でも接触型の強茹や 強制わいせつ, もしくは殺人, 強盗, 放火, 強茹と いった凶悪犯罪の犯罪経歴を有していた者は数パー セントに過ぎなかった。 したがって, 露出犯が, 接 触型の性犯罪歴や凶悪犯罪歴を過去に有している比 率は高くないと考えられる。冒頭に述べたように，

Abel and Osborn ${ }^{4)}$ の海外の研究では, 露出症者の うち, 窃視症, 窃触症, 強姦, 非近親姦的抒よび近 親娞的小坚性愛といった他の性喏好障害や犯罪的行 為が同時に認められた者がそれぞれ 1 割から 3 割弱 程度認められたが，少なくとも犯罪経歴を分析する 限りにおいては，今回分析対象となった露出犯にお いてそのような傾向は確認できなかった．ただし， 今回分析対象となった露出累犯者の $7 \%$ が過去に強 制わいせつ歴を有していたことは, 露出と強制わい せつを両方敢行する者が一定数存在することを示唆 している.

さらに, 露出累犯者の手口を異なる検挙時で比較 した結果, 前述した露出の主特徵である, 昼間や 10 歳代から20歳代の被害者に対する犯行といった手口 については，比較的一致する傾向が見出された．た だし，これは，元の構成比が大きいことによる結果 であると考えられた. 他方, 「電車・バス」や「公 共空間」といった犯行場所については, ASRや FSC によって分布の偏りを補正しても一致率が高 かった。 その一方で, 出現頻度のより低い, 夜間や 30 歳代以上の被害者といった特徵が一致する割合
は，それらより低かった。この結果は，30歳代以上 の女性が被害者である場合には，機会的な要因でそ れらの被害者が選択された可能性が高く, 被害者の 年齢層が高い場合，犯人にとって被害者の年齢層は 大きな意味を持たない場合が多いことを示唆してい ると考えられる.

以上述べた本研究の結果は, 露出犯の特徵や行動 の移行性の一面を計量的に示したものであり, 露出 に対する防犯対策や捜査活動, および露出症の心 理・精神療法を行う上で活用可能な基礎的な知見で あると考えられる. 露出に関する先行研究は散見さ れるものの, 分析対象が露出症と診断された者に限 定されていたり4), 経験的もしくは臨床的知見から 露出犯について考察したものが多く1,3,5), 露出に関 する実証的研究はほとんど見当たらない. 本研究 は, 警察が検挙した露出犯について全国的なデータ を収集し，その特徵や累犯者の行動の移行性につい て実証的に検討したという点において一定の意義を 持つと考えられる.

まず，昼間の時間帯や10歳代から20歳代の被害者 が対象となりやすく, 異なる検挙時に抢いてもそれ らの特徵が反復されやすいという結果を踏まえれ ば, 露出事件が発生した際の各種の警察活動は, 昼 間，10歳代や20歳代の女性が通行する可能性の高い 場所（たとえば，高校生が比較的よく通るであろう 通学路）を集中的に行うべきであることを示してい る.そして, 比較的年齢層の高い被害者が対象とな った事件が発生した場合であっても, 犯人が状況的 要因で機会的にそれらの女性を対象とした可能性が 低くないことから, 同一犯人による次回犯行の犯行 形態を予測する際には，10歳代から20歳代の被害者 が対象となる可能性をより高く見積もるべきであ る.

また，犯人検挙のための捜査活動において，捜査 エリアや捜査対象者の優先順位付けを行う際には, 犯行現場から $3 \mathrm{~km}$ 以内に居住している者, 犯罪経 歴保有者がそれぞれ半数程度を占めること, 犯罪経 歴のなかで該当する可能性が高いのはわいせつであ ること, 仮に同種の犯罪経歴を有すると推定する場 合には, 電車・バスに抢ける犯行は異なる検挙時に おいても反復性が高いこと等の知見は活用すべきで 
ある。

さらに，今回分析対象となった露出犯のうちの一 定数が，社会的，経済的に大きな問題なく生活して いたと考えられるという結果は，露出症者に対する 精神療法や心理療法を行う上で考慮すべき知見であ ろう. Sadock and Sadock ${ }^{12)}$ は, 露出症の男性は, 性器を露出し, 被害者の恐怖, 驚愕, 嫌悪などの反 応を見ることで，男らしさの確認をするとしている 他, Bartol and Bartol ${ }^{13)}$ は, 多くの露出症者は脆弱 な自尊心に打撃を受けて不全感とストレスが高ま り，それに続いて露出したいという衝動を感じると 述べている。ささらに, 大江ら ${ }^{14)}$ は, 性非行のリスク 要因の一つとして, 社会的安定性や適応をあげた上 で，治療や処遇にあたって環境調整に重点を置くこ との重要性を述べているが，露出犯の場合において も，環境からのストレスが自尊心への打撃となり， 露出の契機になっている例は少なくないと考えられ る.すなわち, 社会的, 経済的に大きな問題なく生 活していた者が露出に至る心理社会的な背景として は，仕事や家庭生活等に拈けるストレスが大きくな り, 元々有していたであろう性的欲求の抑制が困難 となり, 性犯罪の中でも被害者との接触がほとんど ないために，逮捕リスクが低く，かつ被害者への身 体的な加害行為のない露出に及んだことが可能性と して考えられる。性嗜好異常の治療として, Sadock and Sadock ${ }^{12)}$ は, 幾つかの精神医学的な介入 方法を挙げた上で, 特に, 洞察試行的精神療法にお いては，治療を受けることで，自分を性的な衝動行 為に駆り立てる日々の出来事を知るようになり，よ り上手く日常のストレスに対処できるようになり， 人生の伴侶と関係を築くための能力を増やすことが できるとしている12). 前述したような, 日常生活に おける高ストレスが犯行の大きな引き金になってい る者に対する療法においては特に，彼らが犯行に至 ってしまった心理社会的な背景を配慮した関わりや 周囲の人々の関わり方を含めた環境調整, ならびに 日常のストレスに対処できる能力を強めることが必 要であろう。

また，今回分析対象となった露出犯 414 人のう ち，3 割近くがわいせつの犯罪経歴を有していた 他, 露出累犯者であると特定された者が全体の $21 \%$
を占めたとの結果は, 露出を繰り返す者が少なくな いことを示す。特に, 露出の場合, ストレスを受け たあとや無力感を持ったあとに，好ましい被害者に 露出することができるならば, 露出は不快な感情状 態に対する有効な方法として学習された反応となる ため, 反復的に行われ，消去されにくいと考えられ る13). 近年, 法務省に抢いて, 認知行動療法の理論 を基礎とした再犯防止プログラムとして, 刑事施設 内に扔ける性犯罪再犯防止指導や保護観察における 性犯罪者処遇プログラムが組織的に実施されている が15), 本研究で分析対象となった露出犯の 2 割から 3 割が過去にも同様の事件で検挙されていたとの結 果は, 露出犯においてもこうした再犯防止プログラ ムが重要であることを示している.

ただし, 本研究では限られた事件資料を元にコー ディングしたデータを用いたため, 犯人の被害者へ の接触方法といった詳細な犯行特徵や, 犯人の対人 行動様式といった特徵等, 重要な変数が欠落してい る. また, 露出で検挙された者が, 過去に露出以外 の性的逸脱行為を行っているか否かを正確に把握す るためには, 警察が把握していない事件の暗数が多 いことが考えられるため, 犯罪経歴からのみ検討す るのではなく，臨床場面等で彼らから直接面接をし て聴取する必要があるだろう。したがって, 露出犯 の行動についてより詳細に検討するためには, 研究 目的に則した調查を実施し, より詳細なデータを収 集する必要があると考えられる。

今後は, 本研究で見出された知見を元に, 犯罪者 が露出に至る心理プロセスについてより多面的に検 討することによって, 露出犯についてさらに深いレ ベルでの理解が可能になると考えられる.

\section{文 献}

1）針間克己, 露出症. 別冊日本臨牀 領域別症候 群シリーズ, 39, 288-290, 2003.

2) American Psychiatric Association, Diagnostic and statistical manual of mental disorders. 4th ed., Text Revision. American Psychiatric Association, Washington, D. C., 2000. (高橋三郎, 大野 裕, 染矢俊幸 (訳) DSM-IV-TR 精神疾患の診 断・統計マニュアル. 医学書院, 東京, 2003.) 
3) Davison G. C., Neale J. M. and Kring A. M., Abnormal psychology. 9th ed., John Wiley \& Sons, Inc., New Jersey, 2004. (下山晴彦（編訳） テキスト臨床心理学 5一ライフサイクルの心理 障害. 誠信書房，東京，2007.)

4) Abel G. G. and Osborn C., The paraphilias: The extent and nature of sexually deviant and criminal behavior. Psychiatr. Clin. North Am., 15, 675-687, 1992.

5）針間克己，性非行少年の心理療法. 有斐閣, 東京, 2001 .

6）内山絢子, 及川里子, 加門博子, 高校生 · 大 学生の性被害の経験. 科学警察研究所報告防犯 少年編，39, 32-43, 1998.

7）原田 豊, 鈴木 護, 推移行列を用いた1970 年生まれ少年の非行種別の推移に関する研究. 科学警察研究所報告防犯少年編, 34, 165-181, 1993.

8）渡邊和美, 年少者強姦事件の犯人像, 渡辺昭 一(編) 捜査心理学. pp. 160-176, 北大路書房, 京都, 2004.

9）長澤秀利, 性犯罪のプロファイリング一強制 わいせつ, 田村雅幸（監）高村 茂, 桐生正幸 (編) プロファイリングとは何か. pp. 119-133, 立花書房, 東京, 2000.
10）菅 民郎，らくらく図解統計分析教室．オー 么社, 東京, 2006.

11）藤岡淳子, 性暴力の理解と治療教育. 誠信書 房, 東京, 2006.

12) Sadock B. J. and Sadock V. A., Kaplan \& Sadock's synopsis of psychiatry: Behavioral sciences/clinical psychiatry. 9th ed., Lippincott Williams \& Wilkins, Philadelphia, 2003. (井上令 一, 四宮滋子（監訳）カプラン臨床精神医学テ キストーDSM-IV-TR 診断基準の臨床への展開 第 2 版. メディカル・サイエンス・インターナ ショナル，東京，2004.)

13) Bartol C. R. and Bartol A. M., Criminal Behavior: A psychosocial approach. 7th ed., Pearson Education, Inc., New Jersey, 2005. (羽生和紀 (監訳) - 横井幸久, 田口真二（編訳）犯罪心理 学一行動科学のアプローチ. 北大路書房, 京 都, 2006.)

14）大江由香, 森田展彰, 中谷陽二, 性犯罪少年 の諸特性と性非行の反復傾向との関係一日本語 版 J-SOAP-II の適用性の検証. 犯罪学雑誌,

73, 165-173, 2007.

15）法務省法務総合研究所，犯罪白書 平成24年 版. 日経印刷，東京，2012. 